American Journal of Environmental Sciences 8 (3): 328-333, 2012

ISSN 1553-345X

(C) 2012 Science Publications

\title{
Microfinance and Sustainable Livelihood: A Conceptual Linkage of Microfinancing Approaches towards Sustainable Livelihood
}

\author{
${ }^{1}$ Abul Bashar Bhuiyan, ${ }^{1}$ Chamhuri Siwar, ${ }^{2}$ Abdul Ghafar Ismail and ${ }^{3}$ Md. Aminul Islam \\ ${ }^{1}$ Institute for Environment and Development (LESTARI), \\ Universiti Kebangsaan Malaysia (UKM), Bangi- 43600, Selangor, Malaysia \\ ${ }^{2}$ Research Center for Islamic Economics and Finance, \\ Natio Universiti Kebangsaan Malaysia (UKM), Bangi 43600, Selangor, Malaysia \\ ${ }^{3}$ Faculty of Business and Technoprenuership, Universiti Perlis Malaysia, Malaysia
}

\begin{abstract}
The aim of this study is to discuss about the conceptual explanation of microcredit and sustainable livelihood Moreover, this study also described about conceptual linkages of microcredit towards a sustainable livelihood framework. The study found that the providing accesses of microfinancing are potentially working in the way of ensuring sustainable livelihood of the poor women in the world. The study recommended that zakat based Islamic mode of financing and Qard-alHasan on the basis of spiritual values would be an alternative model for poverty alleviation and ensuring sustainable livelihood.
\end{abstract}

Key words: Microcredit and microfinance, sustainable livelihood, qard-al-hasan

\section{INTRODUCTION}

Sustainable livelihood is a key agenda for ensuring the capabilities, assets and activities required for a means of living in the present world. Moreover means 'the livelihood when it can cope with and recover from external stress and shocks and maintain or enhance its capabilities and assets now and in the future. From the begging of civilization it is destroying human basic rights and depriving them through involving of multiple dimensions from limited income, vulnerability, lack of essential assets and opportunities in the face of shocks too few possibilities to participate in collective decision making for every human is entitled (David and Jonathan, 2009). The economist and the policy makers have invented multiple numbers of strategies for sustainable livelihood and theories as well as clear relevant the conceptual issues over the time (Bhuiyan et al., 2010; 2011a; 2011b).

Since last three decades microcredit has been launched as one of the prime strategies in the overall movement to end of the poverty and ensuring Sustainable livelihood (Hossain, 1988). Participatory approach realized that poor as well as the lower income group are facing major problems is access to credit. Their lack of assets for collateral, lack of financial records and limited credit history has made almost impossible for them to obtain credit from the formal financial institutions. Due to lack of capital, the poor are tied to low productivity, usual self-employed economic activities. Thus, providing the poor with credit will generally help to solve the problem of the poor. In this regards, microfinance program is generally perceived as one of the practical and attractive means for providing accessibility of the poor to credit and hence reducing poverty and achieving of sustainable livelihood (Bhuiyan et al., 2011a; 2011b).

In such situation, it is more important to how micro financing and sustainable development for linking together in the way of sustainable livelihood of the borrowers. Thus, the aim of this study is to draw out the linkages with poverty and sustainable livelihood and existing relevant concepts.

\section{Conceptual framework:}

Microcredit and microfinance: The word 'credit' comes from the Latin word 'credo' meaning 'to believe' or 'To trust'. Hence 'credit' entails someone, the lender, to believe or to trust someone, the borrower, with funds to be used by the borrower for his or her purposes (i.e., Business, Consumption) to be repaid to the lender with interest at a later stage on agreed terms and conditions (Rahman, 2005). The term microfinance and microcredit are generally used interchangeably since microfinance embraces microcredit and means as

Corresponding Authors: Abul Bashar Bhuiyan, Institute for Environment and Development (LESTARI),

Universiti Kebangsaan Malaysia (UKM), Bangi- 43600, Selangor, Malaysia 
the provision of microloans with savings, Insurance. A service where as microcredit offer only small tiny loan.

"Microcredit is a program designed to extend small loans to very poor people for self employment projects that generate income, allowing them to care for themselves and their families" (Daley-Harris, 2009). On the other hand, "Microcredit refers to micro loans, whereas microfinance offer to small loans with other financial service as well as savings, Insurance and it is appropriate where NGO's and other MFI's are involved to supplement the loans with other financial services as well as savings, Insurance" (Sinha, 1998).

In the same way, "Microcredit is a component of microfinance which is used to provide a small credit to the poor people but microfinance also involves additional non credit financial service such as savings, insurance, pensions and payment service (Buckley, 1997). furthermore "Microfinance as the practice of offering small, collateral free loans to members of cooperatives who otherwise would not have access to the capital necessary to begin a small business or other income generating activities"-- (Hossain et al., 2004).

Another definition has drawn that "Microfinance as the provision of a wide range of financial services like saving accounts, loans, payment services and insurances for people with no regular access to financial services through traditional financial institutions". On the other hand "Microcredit institutions will often make loans to clients rejected by commercial bank and therefore there is normally little competition between microcredit. The principal advantage of financing through microcredit programs is that these programs are willing to those lacking collateral. Subsidiary advantages include creating a credit history of the borrower and instilling a sense of responsibility through the need for repayment (Pretes, 2002).

Moreover, "Microfinance as the appropriate attempt to improve access to very small loans for poor household neglected by banks -- (Schreiner and Colombet, 2001). Microcredit is the method of loaning of a small amount of money $(\$ 5-\$ 100)$ to the needy but capable people without any collateral security for Income Generating Activities (IGAs) as well as enabling them self- reliant.

From the above discussion this study defines about microfinance as "The provision of access of a small amount of credit to the poor those not having assets for collateral, no financial records and credit history as well for Income Generating Activities (IGAs) to alleviate poverty and ensure livelihood development through improving of good health, access of children's education, achieved skill, acquiring assets, take part social activities.

The concept of sustainable livelihood: The concept of 'sustainable livelihood' is increasingly important in the development debate. The term 'Sustainable Livelihood (SL) came as a revolutionary development concept in the early 1990s, drawing on advances in understanding of famine and food insecurity during the 1980s. Sustainable Livelihood (SL) comprises the capabilities, assets and activities required for a means of living. Moreover means 'the livelihood when it can cope with and recover from external stress and shocks and maintain or enhance its capabilities and assets now and in the future. Moreover "The sustainable development means of meeting the needs of the present without compromising the ability of future generations to meet their own needs" (Lebel and Kane, 1987). Furthermore, "A livelihood comprises the capabilities, assets (including both material and social resources) and activities required for a means of living. A livelihood is sustainable when it can cope with and recover from stresses and shocks" (Chambers and Conway, 1992).

In the same way, Sustainable Livelihood (SL) is a way of thinking regarding the issues of objectives, scopes and priorities for development, in order to enhance progress in poverty elimination. It is a holistic approach that tries to capture and provide a means of understanding, the vital causes and dimensions of poverty without collapsing the focus onto just a few factors (e.g. economic issues, food security). It also tries to sketch out the relationships between the different aspects (causes, manifestations) of poverty, allowing for more effective prioritization of action at an operational level (DFID, 2001). Furthermore, the Department for International Development (DFID) introduces an action project in1997 to supporting policies and actions which promote sustainable livelihoods'. This is one of three objectives, designed to help achieve the overall aim of poverty elimination. Since 1997, various groups within DFID have been working to develop a better understanding of how to operationalise this sustainable livelihoods objective. The process has entailed extensive consultation with partners as well as reflection on early efforts to implement sustainable livelihoods approaches (DFID, 2001).

DFID identified in their work that Sustainable Livelihoods Approaches (SLA) would be the way of hope to help people to achieve lasting livelihood improvements measured using poverty indicators that they, themselves, define (Fig. 1). This, in turn helps to combat exclusion. It is people-centered. It recognizes that people have certain rights but also certain responsibilities to each other and to society more generally. It recognizes the enormous diversity amongst the 1.3 billion extremely poor people in the world and stresses the strengths of these people. If we want to make a difference we must build on these strengths, helping people to move in the directions that they want to move (DFID, 2001). 


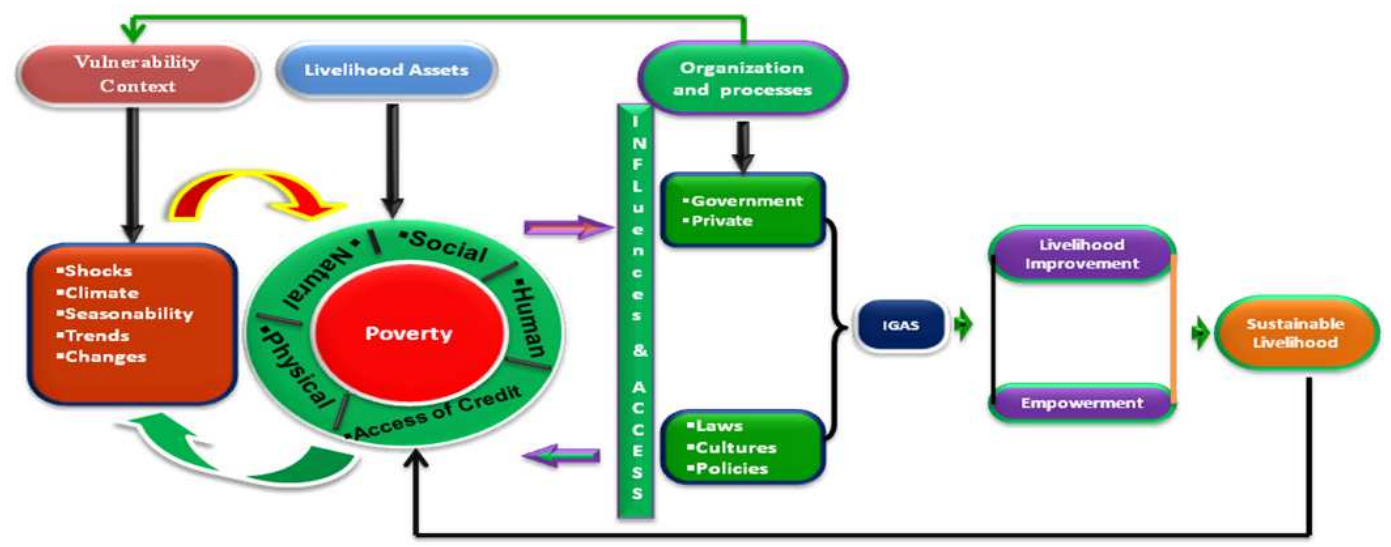

Fig. 1: Conceptual link of microcredit and sustainable livelihood Source: Modified from the (DFID, 2001)

Sustainable livelihood framework: The SL framework is the process of form which is 'organize' various factors that constrain or enhance livelihood opportunities and that affect how these people create a livelihood for themselves and their households. Closest to the people at the center of the framework are the resources and livelihood assets that they have access to and use. These can include natural resources, technologies, their skills, knowledge and capacity, their health, access to education, sources of credit, or their networks of social support. The extent of their access to these assets is strongly influenced by their vulnerability context, which takes account of trends (for example, economic, political and technological), shocks (for example, epidemics, natural disasters, civil strife) and seasonality (for example, prices, production and employment opportunities). Access is also influenced by the prevailing social, institutional and political environment, which affects the ways in which people combine and use their assets to achieve their goals. These are their livelihood strategies.

Vulnerability context: The poor people are generally living in the vulnerable situations within the turnover of trade and global trend, shock from the social and cultural network as well as unstable market prices and finally depleting from the natural resources. If the poor are able to access the livelihood assets they require and are adequately supported by service providers and enabling agencies and if they are able to make markets, politics, rules and norms work to their advantage, then it should help them to cope with those elements of their vulnerability context which they can do little to change. The representation of the vulnerability context as "allembracing" for the poor, but mediated by the interplay of the other elements in their livelihoods, emphasizes the responsibility of development interventions to help the poor to cope with vulnerability factors.
Livelihood assets: The ability to pursue different livelihood strategies are dependent on the basic tangible and intangible assets that people have in their possession. Drawing on an economic image, such livelihood resources may be seen as the 'capital' base from which different productive streams are derived from which livelihoods are constructed. According to (Ahmed et al., 2011) 'Capital' is conventionally seen as the stock of productive resources built up by human action by investing current income streams and so increasing future benefits from a given input of labor or raw material. The poorest households combine a variety of resources to which they have access in different ways to continue their livelihoods and these resources are called livelihood assets (Hossain et al., 2010). There are five livelihood assets belongs to smooth sustainable life which has identified by DFID (2001) such as (i) Human capital (ii) Physical capital (iii) Financial capital (iv) Social capital (v) Natural capital (DFID, 2001).

Human capital: Human capital is one of the most important livelihood assets which contain upon the household members' skills, knowledge and ability to work that together enable people to pursue different livelihood strategies (Allison and Ellis, 2001; DFID, 2001). As the study has an aim to assess the microcredit role on the respondent livelihood improvement. The following survey output would be able to give an empirical evidence how credit contributions to the improvement of their livelihoods.

Physical capital: Physical Capital is one the most important element which belongs to sustainable livelihood issues. Physical capital is important not only for meeting people's needs directly, but also for providing access to other capital (e.g., through transport 
and infrastructure). In particular, Physical Capital means the resources created by people to support their livelihood (at the household level: buildings, boat, bicycle, agricultural equipments, drinking water, electricity, communication systems as well as equipment and machinery needed to support livelihoods) (Allison and Ellis, 2001; Krantz, 2001; Scoones, 1998). Furthermore, Out of these tangible and intangible assets people construct and contrive a living, using physical labor, skills, knowledge and creativity. Thus, people pursue a range of livelihood outcomes (more income, food security, health security, reduced vulnerability) through different activities, by drawing on a range of assets (Chambers and Conway, 1992).

Financial capital: Financial capital is one of the main supporting elements of resources which are essential for the pursuit of any livelihood strategy such as: Cash income, savings, supplies of credit and regular remittances or pensions (DFID, 2001).

Social capital: Social capital is taken to mean the social resources such as networks, social claims, social relations, affiliations, associations. In particulars, the poor they access within the networks and connectedness that increases people's trust and ability to work together and expand their access to wider institutions, such as political or civic bodies. On the other hand, the membership of more formalized groups which often entails adherence to mutually-agreed or commonly accepted rules, norms and sanctions; and the relationships of trust, reciprocity and exchanges that facilitate co-operation reduce transaction costs and provide for informal safety nets amongst the poor (Krantz, 2001; Scoones, 1998).

Natural capital: Natural capital refers to natural resources made up of land, water, soil, mineral, plant, fisheries, animal life and environmental. Within the sustainable livelihoods framework, the relationship between natural capital and the vulnerability context is particularly close. Many of the shocks that devastate the livelihoods of the poor are themselves natural processes that destroy natural capital (e.g., fires that destroy forests, floods and earthquakes that destroy agricultural land) and changes in the value or productivity of natural capital (Chambers and Conway, 1992).

Transformation structures and processes: The framework are on the various external factors that affect on the poor access of the different forms of assets as well as get feedback with the exchange of these assets (Krantz, 2001). The existing structure and running process are directly enabling them to access of both assets and activities they need. On the other hand, transforming the structure and process are forming within combination of various institutions and organizations (Scoones, 1998). A broad definition of institutions, derived from the sociological and anthropological literature is taken here. This sees institutions as 'regularized practices (or patterns of behavior) structured by rules and norms of society which have persistent and widespread use' (Giddens, 1979). Institutions may thus be formal and informal, often fluid and ambiguous and usually subject to multiple interpretations by different actors. Power relations are embedded within institutional forms, making contestation over institutional practices, rules and norms always important. Institutions are also dynamic, continually being shaped and reshaped over time. They are thus part of a process of social negotiation, rather than fixed 'objects' or 'bounded social systems (DFID, 2001).

Livelihood strategies: The livelihood strategies is whatever the poor people are doing for surviving in the situations of turnover of trade and global trend, shock from the social and cultural network as well as unstable market prices and finally depleting from the natural resources (Hossain et al., 2010). On the other hand, the livelihood strategies are the way of poor efforts to move out themselves from the vulnerable context through existing structures and running process by use of their existing assets and financial access in the income generating activities (Allison and Ellis, 2001; Tschakert et al., 2007). The other main livelihood strategies are access of education; take care of good health and Enhance natural resources.

Livelihood outcome: The livelihood outcomes are what poor households actually achieved by applying their livelihood strategies. The outcomes of livelihood would be sustainable if the people able to ensure secure recovery from external stress and shocks and maintain or enhance its capabilities and assets now and in the future or they able to maintain a good standard of living, actively participate in social well-being activities, reduces of vulnerability and stress and shocks and increase consciousness of maintaining natural resources as well (Allison and Ellis, 2001; DFID, 2001; Krantz, 2001; Tschakert et al., 2007).

Link of microcredit and sustainable livelihood: Microfinance as the practice of offering access of small credit with collateral security free to members of cooperatives who otherwise would not have access to the capital necessary to begin a small business or other 
income generating activities to alleviate poverty. It has been recognized as a powerful and effective tool for combating poverty, the poor access to credit has been rapidly expanding over the past few decades in the area of hopeless and helpless hunger society over the world (Basher, 2010; Hossain, 1988; Hassan and Tufte, 2001; Morduch, 1999; Schreiner, 2003).

Bangladesh is the one of the most growing up developing countries as well as most density of population in terms of the number of the population living and land area in the world. Last three decades the Bangladesh economy could not able to achieve a rapid macro-economic development and strong track record of tackling poverty due to Natural disasters as like as floods, cyclone, riverbank erosion and as well as the political unrest and misused or unused of national resources the economical development of Bangladesh is not most remarkable but impressive.

\section{CONCLUSION}

As the main aim of this study, is to discuss about the conceptual explanation of microcredit and sustainable livelihood of the borrowers. Moreover, from discussion of empirical evidence the study output revealed that there is much contribution of microcredit towards the sustainable livelihood of the poor borrowers. The study also concluded that microcredit is providing the poor the accessibility for the credit to increase their total family through different livelihood strategies of Income Generating Activities (IGAs) and thus, sufficient income provides a hope to the poor to ensure achievement of sustainable livelihood by improving good health, access of children's education, achieved skill, acquiring assets, take part social activities. After those achievements they acknowledge themselves as important parts of family members that means other family members honor about their opinion in the time of decision making. Furthermore, at the end above successive factors microcredit borrowers able to ensure opportunity of sustainable livelihood if all other livelihood assets remain constant.

\section{REFERENCES}

Ahmed, F., C. Siwar and N.A.H. Idris, 2011. The sustainable livelihood approach: Reduce poverty and vulnerability. J. Applied Sci. Res., 7: 810-813.

Allison, E.H. and F. Ellis, 2001. The livelihoods approach management of small-scale fisheries. Marine Policy, 25: 377-388. DOI: 10.1016/S0308597X (01)00023-9

Basher, M.A., 2010. Promotional role of microcredit: Evidence from the Grameen Bank of Bangladesh. J. Int. Dev., 22: 521-529. DOI: 10.1002/jid.1583
Bhuiyan, A.B., C. Siwar, A.G. Ismail and B. Talib, 2010. Grameen credit and poverty: A review of Grameen bank's performance on poverty alleviation in Bangladesh. Int. J. Sustain. Soc.

Bhuiyan, A.B., C. Siwar, A.G. Ismail and B. Talib, 2011a. Financial sustainability and outreach of MFIs: A comparative study of aim in Malaysia and RDS of Islami Bank Bangladesh. Australian J. Basic Applied Sci., 5: 610-619.

Bhuiyan, A.B., C. Siwar, A.G. Ismail and B. Talib, 2011b. Islamic Microcredit is the way of alternative approaches for eradicating poverty in Bangladesh: A review of the Islamic bank Microcredit scheme. Australian J. Basic Applied Sci., 5: 221-230.

Buckley, B., 1997. Microfinance in Africa: Is it either the problem or the solution? World Dev., 25: 1981-1093.

Chambers, R. and G. Conway, 1992. Sustainable Rural Livelihoods. 1st Edn., Institute of Development Studies, University of Sussex, Brighton, ISBN-10: 0903715589, pp: 42.

Daley-Harris, S., 2009. State of the Microcredit Summit Campaign Report 2009. 1st Edn., Microcredit Summit Campaign, ISBN-10: 0980154006, p: 80.

David, R. and M. Jonathan, 2009. The impact of microcredit on the poor in Bangladesh: Revisiting the Evidence. Center for Global Development.

DFID, 2001. Briefing sustainable livelihoods and poverty elimination dfid. 2001 Department for International Development.

Giddens, A., 1979. Central Problems in Social Theory: Action, Structure and Contradiction in Social Analysis. 1st Edn., University of California Press, Berkeley, ISBN-10: 0520039750, pp: 294.

Hassan, M.K. and D.R. Tufte, 2001. The X-efficiency of a group-based lending the case of the Grameen bank. World Dev., 29: 1071-1082. DOI: 10.1016/S0305-750X (01)00014-6

Hossain, A., M. Hossain and K. Rezaul, 2010. Impact of microfinance operations on the livelihood of the clients: A review of the existing literature. Digital Bus., 21: 166-174. DOI: 10.1007/978-3-64211532-5_19

Hossain, M., 1988. Crédit for Alleviation of Rural Poverty: The Grameen Bank in Bangladesh. 1st Edn., International Food Policy Research Institute, Washington, D.C., USA., ISBN-10: 0896290670, pp: 89.

Hossain, M., T.R. Paris and M.L. Bose, 2004. Nature and impact of women's participation in economic activities in rural Bangladesh. Center for Policy Dialogue (CPD), Bangladesh. 
Krantz, L., 2001. The sustainable livelihood approach to poverty reduction. SIDO, Division of Policy and Socioeconomic Analysis.

Lebel, G.C. and H. Kane, 1987. A guide to our common future. The Bruntland Report, World Commission on Environment and Development.

Morduch, J., 1999. The role of subsidies in microfinance: Evidence from the Grameen Bank. J. Dev. Econ., 60: 229-248.

Pretes, M., 2002. Microequity and Microfinance. World Dev., 30: 1341-1353.

Rahman, M., 2005. Micro credit in poverty eradication and achievement of MDGs: Bangladesh experience. Bangladesh Rural Development Board, Dhaka, Bangladesh.

Schreiner, M. and H.H. Colombet, 2001. From Urban to Rural: Lessons for Microfinance from Argentina. Dev. Policy Rev., 19: 339-354. DOI: 10.1111/1467-7679.00138
Schreiner, M., 2003. A cost-effectiveness analysis of the Grameen bank of Bangladesh. Dev. Policy Rev., 21: 357-382.

Scoones, I., 1998. Sustainable Rural Livelihoods: A Framework for Analysis. 1st Edn., Institute of Development Studies, ISBN-10: 1858642248, pp: 22.

Sinha, S., 1998. Informal credit transactions of microcredit borrowers in rural Bangladesh. IDS Bull., 29: 66-80. DOI: 10.1111/j. 1759-5436.1998. mp29004008. $\mathrm{x}$

Tschakert, P., O.T. Coomes and C. Potvin, 2007. Indigenous livelihoods, slash-and-burn agriculture carbon stocks in eastern Panama. Ecol. Econ., 60: 807-820. DOI: 10.1016/j. ecolecon. 2006.02.001 